\title{
A novel cell-based 384-well, label-free assay for discovery of inhibitors of influenza $A$ virus
}

This article was published in the following Dove Press journal:

International Journal of High Throughput Screening

II May 2010

Number of times this article has been viewed

Fuli Jia'

Clinton Maddox ${ }^{2}$

Alice $\mathrm{Gao}^{3}$

Louie Tran ${ }^{3}$

William Severson'

E Lucile White ${ }^{2}$

Lynn Rasmussen ${ }^{2}$

Anju Dang ${ }^{3}$

Colleen B Jonsson ${ }^{1,4}$

'Department of Biochemistry and Molecular Biology, Southern Research Institute, Birmingham, AL, USA; ${ }^{2}$ High-Throughput Screening Center, Southern Research Institute, Birmingham, AL, USA; ${ }^{3}$ Corning Life Science, Corning, NY, USA; ${ }^{4}$ Department of Microbiology and Immunology, University of Louisville, Louisville, KY, USA
Correspondence: Colleen B Jonsson Center for Predictive Medicine for Biodefense and Emerging Infectious Diseases, Department of Microbiology and Immunology, University of Louisville, KY 40202, USA

Tel + I 502-852-I339

Email cbjons0I@louisville.edu
Abstract: Resonance wave-guide (RWG) biosensor technology allows label-free measurements of global cellular responses of the dynamic mass redistribution (DMR). We hypothesized that the DMR signals to extracellular stimulations occurring upon entry of a virus, could provide a new approach for the development of physiologically relevant cell-based assays for screening of small molecules. We explored this technology with influenza virus (A/Udorn/72, H3N2) using MDCK and Vero E6 cell lines in a 384-well format. The MDCK cell line assay was optimized with a fibronectin-coated surface microplate with 6000 cells per well that were infected at a multiplicity of infection (MOI) of 1. Under this set of optimized conditions, for the vero E6 cells, an assay window of $1130 \mathrm{pm}$ shift were obtained at 24 hours. The Vero E6 cell line assay was optimized using a poly-D-lysine-coated surface with seeding density of 6000 cells per well that were infected at a MOI of 5. Under this set of optimized conditions for the MDCK cells, an assay window of $>600$ units and $Z$ values of $0.6-0.7$ were obtained at $24 \mathrm{~h}$. A small library of 1120 compounds was screened using the MDCK, which demonstrates the feasibility of the approach for high-throughput screening.

Keywords: small molecule screening, label-free technology, antivirals

\section{Introduction}

The current state-of-the-art of high-throughput screening (HTS) for small molecule discovery of antivirals is limited by existing technology. Current approaches include assays that screen for protein or enzyme activity of viral protein/enzyme-based targets, fluorescent reporters such as luciferase or the cytopathic effect of some viruses on living cells. However, a vast number of viruses are not readily engineered (eg, reverse genetics, infectious clones) to create reporter systems ${ }^{1,2}$ or phenotypes (eg, cytopathic effect, CPE $)^{3,4}$ that permit the facile tracking technology required for HTS measurement of endpoints. Recent developments in label-free technologies for biomoleculebased applications such as those that measure binding (eg, surface plasmon resonance, isothermal titration calorimetry) $)^{5-7}$ and enzyme-based (eg, high-throughput mass spectrometry) hold great promise for providing complementary high-information content for drug discovery screens for viral protein/enzyme-based targets. For cellbased assays, resonance wave-guide (RWG) technology which offers high resolution scanning $(\mu \mathrm{m})$ of individual wells, may address the critical gap in the drug discovery process, by providing a platform for more physiologically relevant HTS cell-based assays of viruses. ${ }^{8}$

In the Corning ${ }^{\circledR}$ Epic $^{\circledR}$ system, the RWG biosensor consists of a glass substrate and a grating-embedding waveguide film of high refractive index. The system measures 
changes in local index of refraction resulting from molecular binding events or the integrated global cellular responses induced by extracellular stimuli. Such cellular responses, termed the dynamic mass redistribution (DMR), may include protein recruitment, endocytosis and receptor recycling, exocytosis, cytoskeletal re-arrangement, increased and decreased cell adhesion or cell proliferation. Changes in the index of refraction are manifested by a shift in resonant wavelength.

As a proof-of-concept system for the proposed Epic ${ }^{\circledR}$ RWG assay development and implementation efforts, we chose the influenza virus. Influenza A viruses, family Orthomyxoviridae, cause a highly contagious respiratory disease (commonly known as 'flu') in humans. Additionally, the avian influenza A viruses, primarily circulating in Asia, are transmitted directly from birds to humans and are more virulent, resulting in fatal pneumonia and multiple organ failure. The high medical impact, cost and disruptive effects of epidemics and pandemics of these viruses continue to garner global attention. ${ }^{9,10,11}$ If this avian virus acquires the ability to transmit efficiently from humans-to-humans, it is expected to cause the next human pandemic, potentially resulting in millions of deaths, making the virus a priority for study. We hypothesized that the Epic $^{\circledR}$ system would provide a viable alternative to the current HTS approaches in antiviral drug discovery for this group of viruses for discovery of new molecular probes for influenza virus. Herein we show that compared to our current HTS for influenza, ${ }^{4}$ the RWG assay reduces the time for signal detection, reagents and number of steps and offers a similar level of sensitivity in detection of antiviral activity.

\section{Material and methods}

\section{Virus stock, cell culture, cell growth and virus infection medium}

Amplified influenza virus stock (A/Udorn/72, H3N2) was prepared in egg allantoic fluid as previously described. ${ }^{4}$ The titer of the stock was $1 \times 10^{7} \mathrm{pfu} / \mathrm{ml}$. Vero E6 cells, (American Tissue Culture Type [ATCC], CRL-1586) and MDCK Cells (ATCC CCL-34), were maintained as an adherent cell line in Dulbecco's modified eagle's medium(DMEM) with phenol red, supplemented with 10\% fetal bovine serum (FBS), $2 \mathrm{mM}$ L-Glutamine and $100 \mathrm{U} / \mathrm{mL}$ penicillin, $100 \mu \mathrm{g} / \mathrm{mL}$ streptomycin at $37^{\circ} \mathrm{C}$ in a humidified $5 \% \mathrm{CO}_{2}$ atmosphere. Cells were passaged as needed and harvested from flasks using $0.05 \%$ trypsin-EDTA. MDCK cells used for the assay were not used past passage 70 and Vero E6 cells were not used past passage 46. Cells were counted and viability was determined by Trypan Blue solution $(0.4 \%)$ using the coulter Brightline Hemacytometer (Hausser Scientific).
Vero E6 Cells were seeded into Epic ${ }^{\circledR}$ 384-Well Cell Assay Microplates in DMEM medium (Cat\# 31053, Invitrogen) contained $0.1 \% \mathrm{FBS}, 0.3 \%$ bovine serum albumin (BSA), 2 $\mathrm{mM}$ L-Glutamine $100 \mathrm{U} / \mathrm{mL}$ penicillin and $100 \mu \mathrm{g} / \mathrm{mL}$ streptomycin. Cells were infected in the same DMEM medium (without FBS serum) which is assigned as virus assay medium for virus infection and drug dilution. We employed Epic $^{\circledR}$ Fibronectin-Coated Cell Assay Microplate from Corning Incorporated Life Sciences (Cat\# 5041), Poly-D-LysineCoated Cell Assay Microplate (not commercially available) and Epic ${ }^{\circledR}$ 384-Well Cell Assay Microplate (Cat\# 5040).

MDCK cells were seeded into Epic ${ }^{\circledR}$ 384-Well Microplate cells in DMEM medium with $1 \%$ BSA, 2 mM L-Glutamine, $100 \mathrm{U} / \mathrm{mL}$ penicillin and $100 \mathrm{ug} / \mathrm{mL}$ streptomycin $100 \mu \mathrm{g} / \mathrm{mL}$ addition which is used for cell seeding medium. Two types of media were compared in virus infection assays: (1) DMEM medium with $3.7 \mathrm{~g} / \mathrm{L}$ sodium bicarbonate and (2) L-15 (Leibovitz, Lonza cat\# 12-700) designed for $\mathrm{CO}_{2}$ free environments, which was buffered by its complement of salt, free base amino acids and galactose substituted for glucose to help maintain physiological $\mathrm{pH}$ control. To optimize cell growth conditions after seeding into 384-well microplates, 2 incubation times for cell growth were tested, $24 \mathrm{~h}$ or $4 \mathrm{~h}$ incubation after seeding into 384-well plates. Epic ${ }^{\circledR}$ Fibronectin-coated cell assay microplates (FN) were used. Vero E6 or MDCK cells were seeded into FN microplates and infected after $4 \mathrm{~h}$ or $24 \mathrm{~h}$ incubation. The DMR signal windows (uninfected cells signal versus infected cell signal) were compared between cell growth for $4 \mathrm{~h}$ and $24 \mathrm{~h}$ incubation before virus infection. The plates were read after $24 \mathrm{~h}$ or $42 \mathrm{~h}$ virus infection as stated in results or figures.

\section{Label-free assay design}

Vero E6 or MDCK cells were seeded into Epic ${ }^{\circledR}$ fibronectincoated or poly-D-lysine-coated 384-well microplates (20 $\mu \mathrm{L} /$ well) with specified cell densities and incubated at $37^{\circ} \mathrm{C} / 5 \% \mathrm{CO}_{2}$ for $4 \mathrm{~h}$. Baselines were read immediately with the Epic ${ }^{\circledR}$ standalone reader after incubation. Virus was added to the 384-well plates at $20 \mu \mathrm{L}$ per well and infected the cells at a specified multiplicity of infection (MOI) per cell in the virus assay medium. Plates were incubated at $37^{\circ} \mathrm{C} / 5 \% \mathrm{CO}_{2}$ incubators and read after $18 \mathrm{~h}, 24 \mathrm{~h}$ and $42 \mathrm{~h}$ virus post-infection.

\section{Optimization of control drug conditions at different viral MOls}

Ribavirin (Cat\# 196066, MP Biomedicals) and amantadine (Cat\# 1260, Sigma) were tested as controls for influenza inhibitors under the optimized assay conditions. The plate 
format was setup as shown in Appendix 1. Cells were plated in 384-well FN and PDL plates (6000 cells/well, 9000 cells/well) and incubated at $37^{\circ} \mathrm{C} / 5 \% \mathrm{CO}_{2}$ for $4 \mathrm{~h}$ prior to drug addition. The drugs were twofold serially diluted in virus assay media, with final concentrations ranging from 2.5 to $40 \mu \mathrm{g} / \mathrm{mL}$ or 0.16 to $40 \mu \mathrm{g} / \mathrm{mL}$. Final DMSO concentration in each well was $0.25 \%$. Cells were infected with influenza $A$ virus $1 \mathrm{~h}$ after drug addition. Plates were read at 18 h, $24 \mathrm{~h}$ and $42 \mathrm{~h}$ post-infection.

\section{DMSO and control drugs}

Three DMSO concentrations were tested in MDCK cells. Cells were seeded into FN microplates at 6000 cells per well and incubated for $4 \mathrm{~h}$. The DMSO was added to cells at final concentration $0.25 \%, 0.5 \%$ and $1 \%$ and following by $1 \mathrm{~h}$ incubation. The cells were infected at an MOI of 1 and incubated for $18 \mathrm{~h}$ before endpoint reading. The $\mathrm{Z}$ factor value was calculated according to DMR signals observed at three DMSO concentrations. Ribavirin was evaluated in dose-response to determine an $\mathrm{EC}_{50}$ value. The $\mathrm{EC}_{50}$ value was defined as a minimum 50\% DMR signal reduction in infected cells with drug addition relative to infected cells without drug.

\section{Compound library and screen}

The Prestwick Chemical Library ${ }^{\circledR}$ was screened in this assay as part of the validation process, which was solubilized at $1 \mu \mathrm{g} / \mu \mathrm{L}$ in DMSO. A total of 1,120 compounds were screened at a single dose using the optimal assay conditions and the plate layout as shown in Appendix 2. MDCK cells were seeded at 6000 cells per well and incubated at $37^{\circ} \mathrm{C} / 5 \% \mathrm{CO}_{2}$ for $4 \mathrm{~h}$. Compounds were added at $10 \mu \mathrm{g} / \mathrm{mL}$ in assay media with a final DMSO concentration of $0.5 \%$ and incubated for $1 \mathrm{~h}$. The cells were infected at an MOI of 1 with influenza A/Udorn/72 virus. The positive control drug, ribavirin, was diluted in assay medium and added to control wells at a final concentration of $10 \mu \mathrm{g} / \mathrm{mL}$ with $0.5 \%$ DMSO. The assay was read at $18 \mathrm{~h}$ virus post-infection using the Epic ${ }^{\circledR}$ standalone reader. Cell seeding and virus addition were dispensed using a WellMate ${ }^{\circledR}$ (Matrix, Hudson, NH) and compounds were added to cells using a Biomek ${ }^{\circledR} \mathrm{FX}$ liquid handler (Beckman Coulter, Fullerton, CA).

\section{Data analysis}

Data was analyzed as published previously., ${ }^{4,12}$ Briefly, the amount of inhibition of cytopathic effect (CPE) was normalized to $100 \%$ of the drug control. Percent cell viability was defined as (test compound/cell control)*100. An active compound, or "hit", was defined as a compound that exhib- ited a $\% \mathrm{CPE}$ inhibition of $>50 \%$ without compromising cell viability. Ten concentrations of each drug were added to 384 well plates to measure the effective concentration at which the drug inhibited cell death at 50\% in the presence $\left(\mathrm{EC}_{50}\right)$ or absence of virus $\left(\mathrm{IC}_{50}\right)$; with the $\mathrm{IC}_{50}$ defined as the cytotoxicity of the drug alone at $50 \%$.

The $\mathrm{Z}$ factor values were calculated from 1 minus $\left(3^{*}\right.$ standard deviation of cell control $\left(\sigma_{c}\right)$ plus $3 *$ standard deviation of the virus control $\left(\sigma_{v}\right) /[$ mean cell control signal $\left(\mu_{\mathrm{c}}\right)$ minus mean virus control signal $\left.\left(\mu_{\mathrm{v}}\right)\right]$. The signal/background (S/B) was calculated from mean cell control signal $\left(\mu_{c}\right)$ divided by the mean virus control signal $\left(\mu_{v}\right)$. The signal/ noise $(\mathrm{S} / \mathrm{N})$ was calculated from mean cell control signal $\left(\mu_{\mathrm{c}}\right)$ minus mean virus control signal $\left(\mu_{\mathrm{v}}\right)$ divided by the (standard deviation of the cell control signal $\left(\sigma_{c}\right)^{2}$ minus the standard deviation of the virus control signal $\left(\sigma_{\mathrm{v}}\right)^{2}$

\section{Results Optimal growth conditions for Vero E6 and MDCK cells}

We set forth to optimize the difference in the signal change of DMR that correlated with the virus infection. In order to generate the largest signal to noise $(\mathrm{S} / \mathrm{N})$ window between infected and uninfected cells, cell growth conditions were optimized in the Epic ${ }^{\circledR}$ microplates. To optimize the growth conditions for Vero E6 and MDCK cells in 384-well plates, we defined the best media for seeding and viral infection based on the DMR signal. For Vero E6 cells, seeding media was DMEM which included supplements as described in methods, while for virus infection we found that DMEM without FBS was optimal. For MDCK cells, we seeded cells in DMEM medium which contained 1\% BSA and $2 \mathrm{mM}$ L-Glutamine, $100 \mathrm{U} / \mathrm{mL}$ penicillin and $100 \mu \mathrm{g} / \mathrm{mL}$ streptomycin. We found L-15 medium (Leibovitz) with supplements as described in the materials and methods section was optimal for virus infection (Data not shown).

Using the optimized media conditions, DMR signals were assessed at $4 \mathrm{~h}$ or $24 \mathrm{~h}$ incubation after seeding into 384-well microplates. At $24 \mathrm{~h}$ virus post-infection, the DMR difference is indicated by a picometer ( $\mathrm{pm}$ ) shift generated by the DMR signal from uninfected cells minus signal from infected cells (Figure 1). After a $24 \mathrm{~h}$ incubation of the Vero E6 cells, the DMR signal difference was a 9 pm shift for 3000 cells per well, a 696 pm shift for 6000 cells per well and a 349 pm shift for 9000 cells per well between virus-infected cells and uninfected cells (Figure 1A). After 4 h, virus-infected Vero E6 cells showed an 1130 pm shift for 6000 cells per well, a 782 pm shift for 9000 cells per well and a 569 pm shift 
for 12,000 cells per well (difference between infected cells and uninfected cells (Figure 1B). The DMR signal difference increased by 1.6 fold $(1130 \mathrm{pm} / 696 \mathrm{pm})$ for cells seeded at 6000 per well versus a 2.2 fold $(782 \mathrm{pm} / 349 \mathrm{pm})$ increase for cells seeded at 9000 per well 4 hours incubation prior to virus infection. After 4 hours, virus-infected MDCK cells showed a $1036 \mathrm{pm}$ shift for 6000 cells per well and a $1031 \mathrm{pm}$ shift for 9000 cells per well between virus-infected cells and uninfected cells (Figure 1C). A similar result was observed at 42 hours post-infection for both cell lines (data not shown). Therefore, the DMR largest signal window was observed for both MDCK and Vero E6 cells was at $4 \mathrm{~h}$. Based on these results, we designed a general assay procedure (Figure 2) for determining the assay parameters that follow.

\section{Viral multiplicity of infection, cell density and incubation times}

The cells density, viral multiplicity of infection (MOI) and incubation time after virus infection were determined by following the general assay design (Figure 2). MDCK cells were seeded into 384-well plates at 6000 and 9000 cells per well and infected at MOIs of 1,2 and 5 at 4 hours after seeding in the 384-well microtiter plates. The DMR signal correlated with viral MOI. DMR values of 722, 892, $977 \mathrm{pm}$ were observed in viral infected-MDCK cells at an MOI of 1 , 2,5 at $18 \mathrm{~h}$ post-infection, respectively. The largest signal window was observed at $42 \mathrm{~h}$ post-infection (Figure 3 ). Cells plated at 6000 cells per well versus 9000 cells per well consistently produced a larger signal window at $18 \mathrm{~h}, 24 \mathrm{~h}$ and $42 \mathrm{~h}$ virus post-infection (Figure $3 \mathrm{~A}$ and $\mathrm{B}$ ). Therefore, an optimal signal window was obtained with $6000 \mathrm{MDCK}$ cells per well, MOI of 1,2 or 5 and reading of the plates either $18 \mathrm{~h}$ or $24 \mathrm{~h}$ post-infection.

Vero E6 cells were infected at an MOI of 0, 0.5, 1 and 5 at 6000 cells per well. The most significant $\mathrm{S} / \mathrm{N}$ window was observed at MOI 5 (data not shown). Therefore, we titrated Vero E6 cells at densities of 6000, 9000 and 12000 cells per well and infected at an MOI of 5 (Figure 3C-E). We found 6000 cells per well produced the largest signal windows of $1130 \mathrm{pm}$ shift and $1753 \mathrm{pm}$ shift (signal from uninfected cells minus signal from virus infected cells) at $24 \mathrm{~h}$ and $42 \mathrm{~h}$ postinfection as compared to the other cell densities (Figure 3C). A cell density of 9000 cells per well produced a $782 \mathrm{pm}$ shift and 1279 pm shift (uninfected cells signal minus virus infected cells) at $24 \mathrm{~h}$ and $42 \mathrm{~h}$ post-infection, respectively (Figure 3D). Overall, the signal window was smallest at 12000 cells per well (Figure 3E). The largest signal window was observed at $42 \mathrm{~h}$ virus post-infection at all three cell densities, but overall the $24 \mathrm{~h}$ virus post-infection timepoint generated the most appropriate signal window (1130 pm shift). Therefore, the optimal assay conditions for Vero E6 were 6000 cells per well with an MOI of 5 to produce the appropriate $\mathrm{S} / \mathrm{N}$ ratio and an endpoint at $24 \mathrm{~h}$ post-infection.

In summary, an approximately $1000 \mathrm{pm}$ shift was obtained when MDCK cells were infected at an MOI of 5 and read $18 \mathrm{~h}$ post-infection (Figure $3 \mathrm{~A}$ and $\mathrm{B}$ ) versus
A

Vero E6 24 h incubation

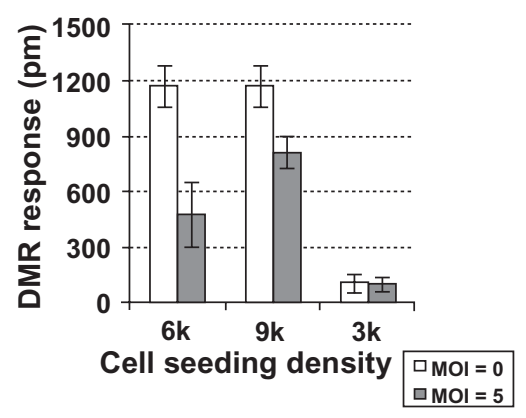

B

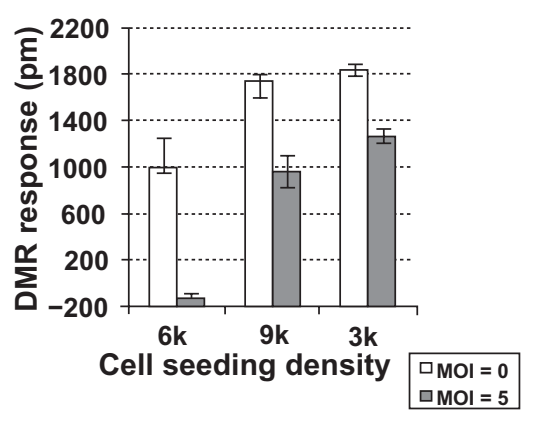

Vero $\mathrm{E} 6$ cells $4 \mathrm{~h}$ incubation

$\square \mathrm{MOI}=5$
C
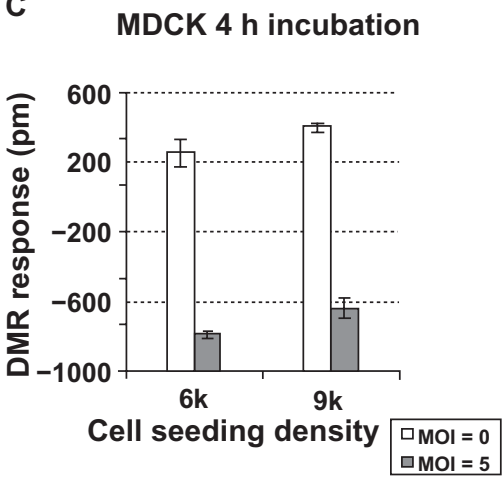

MDCK cells $4 \mathrm{~h}$ incubation

\begin{tabular}{ccc} 
Cell density & DMR difference \\
\hline $6000 /$ well & & $1036 \mathrm{pm}$ \\
9000/well & $1031 \mathrm{pm}$ \\
& N/A & $1036 \mathrm{pm}$ \\
\hline
\end{tabular}

Figure I Optimization of cell growth conditions. Vero E6 and MDCK cells were seeded into Epic ${ }^{\circledR}$ fibronectin-coated plates (FN) and incubated for $24 \mathrm{~h}$ or $4 \mathrm{~h}$ before virus infection with influenza virus $\mathrm{A} / \mathrm{Udorn} / 72$ at an $\mathrm{MOI}$ of 5 . Endpoints were read at $24 \mathrm{~h}$ post-infection. DMR difference equals signals from the uninfected cells minus signals from infected cells as indicated by wavelength picometer (pm) shift. DMR response of A) Vero E6 cells infected after $24 \mathrm{~h}$ cell growth, B) Vero E6 cells infected after $4 \mathrm{~h}$ cell growth and C) MDCK cells infected after $4 \mathrm{~h}$ cell growth. 


\section{General assay design}

Day 1: $\quad$ Plating cells $20 \mu \mathrm{L} /$ well in seeding medium $\downarrow$ Incubate in $\mathrm{CO}_{2}$ chamber for $4 \mathrm{~h}$

Take out plates and read base line $\downarrow$

Add $5 \mu \mathrm{L}$ drug or DMSO in assay medium $\downarrow$ Incubate in $\mathrm{CO}_{2}$ chamber for $1 \mathrm{~h}$ (optional)

Add $20 \mu \mathrm{L}$ virus dilution in assay medium $\downarrow$

Day 2 or 3: Read plate at $18 \mathrm{~h}, 24 \mathrm{~h}$ or $42 \mathrm{~h}$ P.I.

Figure 2 General assay designs. Cells were seeded into specified Epic ${ }^{\circledast}$ microplates and incubated at $37^{\circ} \mathrm{C} / 5 \% \mathrm{CO}_{2}$ for $4 \mathrm{~h}$. Plates were removed from the incubator and a baseline read was performed followed by compound addition. The plates were incubated in $\mathrm{CO}_{2}$ chamber at $37^{\circ} \mathrm{C}$ for $\mathrm{I} \mathrm{h}$ and then virus was added. The plates were read at $18 \mathrm{~h}, 24 \mathrm{~h}$ or $42 \mathrm{~h}$ post- infection (P.I.).

$24 \mathrm{~h}$ post-infection for the Vero E6 cells (Figure 3C-E). The DMR signal response was consistent with the microscope observations (data not shown). A clear dose-dependent, virus-induced CPE was observed for MDCK cells infected at different MOIs as early as $18 \mathrm{~h}$ virus infection under microscopic examination, but no visible $\mathrm{CPE}$ was observed for Vero E6 cells until $42 \mathrm{~h}$ post-infection. Therefore, the virus-induced CPE on MDCK cells was observed $24 \mathrm{~h}$ earlier than Vero E6 cells under microscope examination and $6 \mathrm{~h}$ earlier than the DMR signal response. For MDCK cells, our results support $18 \mathrm{~h}$ as the optimal time post-infection for the assay endpoint. In addition, the virus induced CPE for MDCK cells was also observed at lower MOIs of 1 and 2 at $18 \mathrm{~h}$ post-infection under both microscope examination and DMR signal response (Figure 3A and B). For Vero E6 cells, no CPE was observed at an MOI of 1 until $42 \mathrm{~h}$ post-infection (data not shown). Based on these data, the MDCK cell line was more appropriate for the DMR assay.

\section{Comparison of Epic ${ }^{\circledR}$ microplate coating surface}

The Epic ${ }^{\circledR}$ fibronectin-coated (FN) or poly-D-Llysine (PDL) surface 384-well microplates from Corning were tested under optimized assay conditions for MDCK and Vero E6 cells at 6000 cells per well and an MOI of 5. The DMR signal windows were compared at $24 \mathrm{~h}$ post-infection for Vero E6 cells and at $18 \mathrm{~h}$ post-infection for MDCK cells. Vero
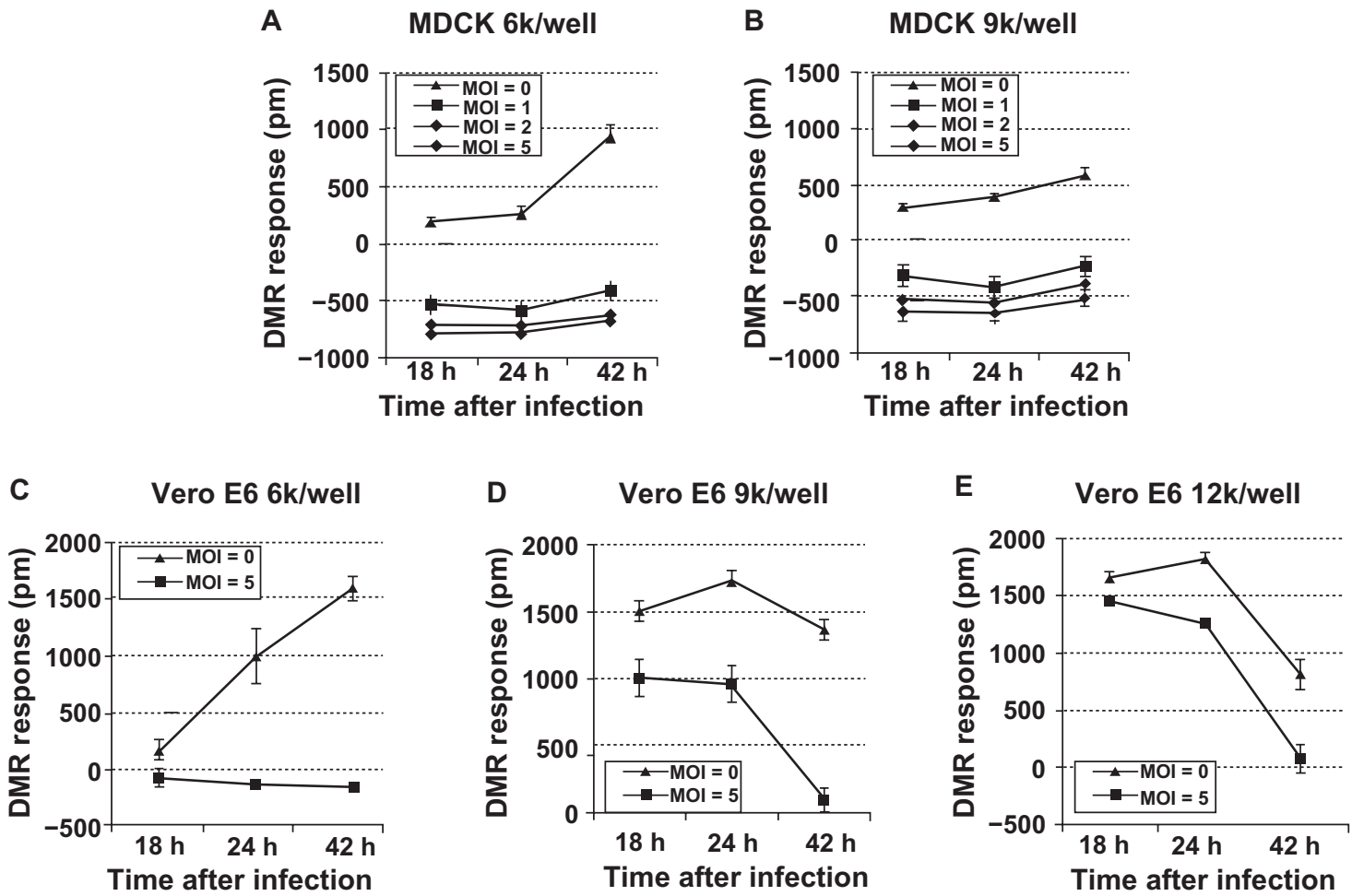

Figure 3 Influenza infection parameters for MDCK and Vero E6 cells. Cell density, MOI and virus incubation time were compared. Cells were seeded at 6000 , 9000 and 12000 cells per well in fibronectin-coated plates. The cells were infected at an MOI of 5 for Vero E6 cells or MOI of I, 2 and 5 for MDCK cells. The plates were read at I8 h, $24 \mathrm{~h}$ and $42 \mathrm{~h}$ after virus infection. DMR response in MDCK cells A) at 6000 cells per well; B) at 9000 cells per well; DMR response in Vero E6 cells C) at 6000 cells per well; D) at 9000 cells per well and E) at 12,000 cells per well. 
E6 cells produced a DMR signal window with an $1130 \mathrm{pm}$ shift in the FN plate and 1207 pm shift (uninfected cells signal minus virus-infected cells signal) in the PDL plate (Figure 4A). The DMR signal window was 77 pm higher in PDL plate than in the FN plate at $24 \mathrm{~h}$ post-infection. Similar results were observed at $42 \mathrm{~h}$ post-infection (data not shown). MDCK cells produced a 977 pm shift in the FN plate and 742 pm shift (uninfected cells signal minus virus-infected cells signal) in the PDL plate (Figure 4B). The DMR signal was 235 pm higher in the FN plate than in the PDL plate at $18 \mathrm{~h}$ post-infection and similar results was observed at $24 \mathrm{~h}$ and $42 \mathrm{~h}$ post-infection (data not shown). Therefore, the PDL coated surface 384-well microplate was selected for Vero E6 cells and the FN-coated 384-well microplate for MDCK cells.

\section{Optimization of control drug conditions at different viral MOls}

Two known influenza virus antivirals were selected to assess the assay performance, ribavirin and amantadine. The control drug concentrations were optimized with MDCK cells seeded at 6000 and 9000 cells per well in FN and PDL 384-well microplates infected with three different MOIs. We measured DMR endpoints at $18 \mathrm{~h}, 24 \mathrm{~h}$ and $42 \mathrm{~h}$ virus post-infection. We found a cell density at 6000 cells per well in the FN plates was optimal (data not shown). The MDCK cells doseresponse curves are shown in Figure 5. The $\mathrm{EC}_{50}$ value of each drug was defined as a minimum 50\% DMR signal reduction in infected cells relative to infected cells without drug.
Ribavirin conferred protection to infected cells at all MOIs tested and at all different time points post-infection. At $18 \mathrm{~h}$, $24 \mathrm{~h}$ and $42 \mathrm{~h}$ post-infection, infected cells showed above $60 \%$ viability at specified ribavirin concentration compared to infected cells without drug. At $18 \mathrm{~h}$ post-infection, the $\mathrm{EC}_{50}$ values were $3.8 \mu \mathrm{g} / \mathrm{mL}, 4.5 \mu \mathrm{g} / \mathrm{mL}$, and $7.5 \mu \mathrm{g} / \mathrm{mL}$ at MOIs 1,2 , and 5 , respectively (Figure $5 \mathrm{~A}$ ). At $24 \mathrm{~h}$ post-infection, the $\mathrm{EC}_{50}$ values were $3.8 \mu \mathrm{g} / \mathrm{mL}, 6.9 \mu \mathrm{g} / \mathrm{mL}$, and $10 \mu \mathrm{g} / \mathrm{mL}$ at MOIs 1,2 , and 5 (Figure $5 \mathrm{~B}$ ). At $42 \mathrm{~h}$ post-infection, the $\mathrm{EC}_{50}$ values were $11.3 \mu \mathrm{g} / \mathrm{mL}, 14.4 \mu \mathrm{g} / \mathrm{mL}$, and $26.9 \mu \mathrm{g} / \mathrm{mL}$ at MOIs 1, 2, 5 (Figure 5C). The earliest timepoint (18 h) and lowest MOI gave the best $\mathrm{EC}_{50}$ value at $15 \mu \mathrm{M}$.

\section{DMSO and ribavirin parameters}

Frequently, chemical compound libraries are resuspended and stored in DMSO as a compound solvent. Previously, we have shown that higher concentrations of DMSO $(>1 \%$ final concentration) affect MDCK cell viability and virus infection. ${ }^{13}$ To maximize the amount of compound in DMSO that can be screened in single dose without compromising cell viability of virus infectivity, 3 DMSO concentrations were tested under the optimal assay conditions defined herein. The DMR signal windows and $\mathrm{Z}$ factor values were compared to 3 different DMSO concentrations. All DMR signal windows show $>1000 \mathrm{pm}$ shift and the average $Z$ values are approximately 0.7 for the three different DMSO concentrations tested (Figure 6). Therefore, the data show that all three concentrations of DMSO do not affect cell viability or virus infectivity and can be used for compound screening.
A

\section{Vero E6 24 h surface comparison}

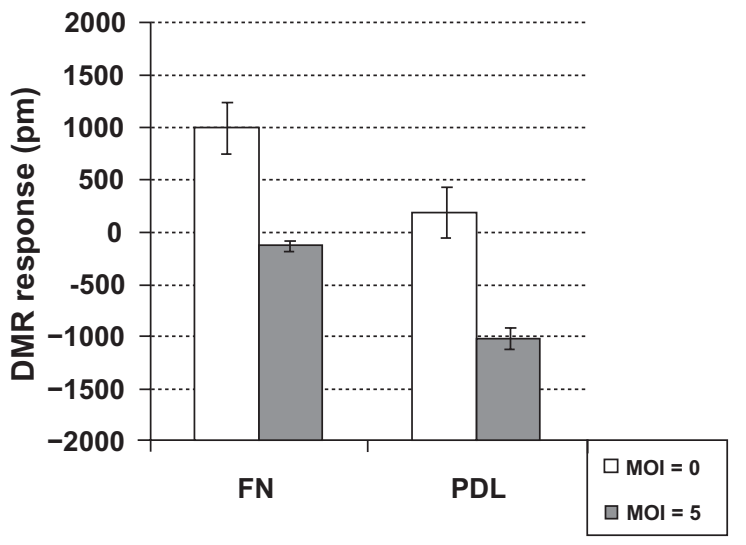

B

MDCK 18 h surface comparison

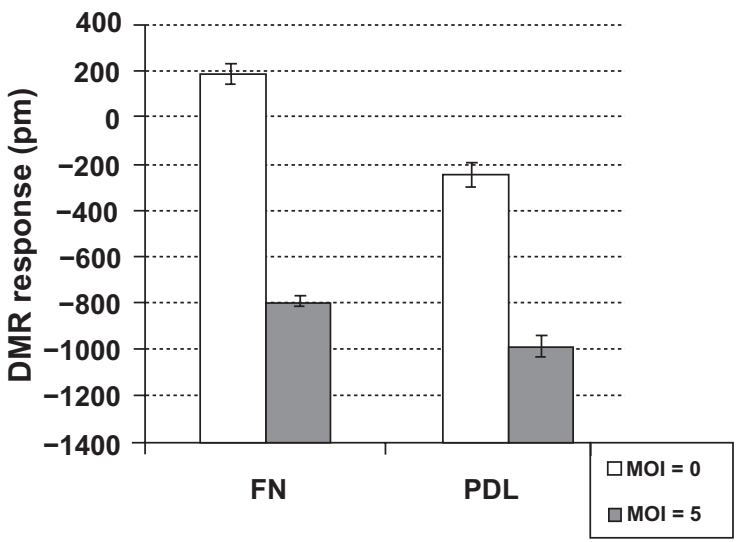

Figure 4 Comparison of signals with fibronectin (FN) or poly-D-lysine (PDL) Epic ${ }^{\circledast}$ microplates. MDCK and Vero E6 cells were seeded into FN or PDL surface coated Epic ${ }^{\circledR}$ microplates at 6000 cells per well and infected at an $\mathrm{MOI}$ of 5, followed by the general assay design. FN and PDL surface comparison with A) Vero E6 cells at $24 \mathrm{~h}$ virus post-infection and $\mathbf{B})$ MDCK cells at $18 \mathrm{~h}$ virus post-infection. 
A

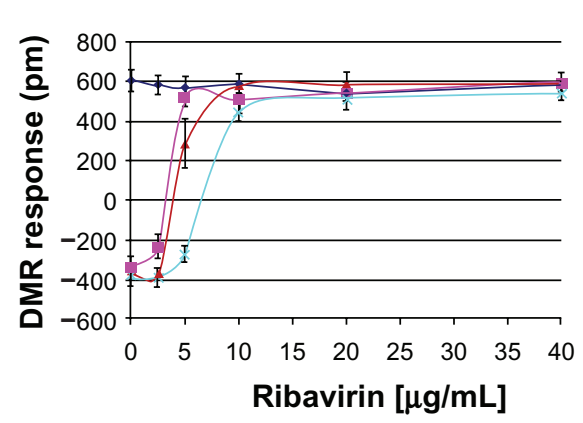

MDCK $18 \mathrm{~h}$ virus P.I.
B

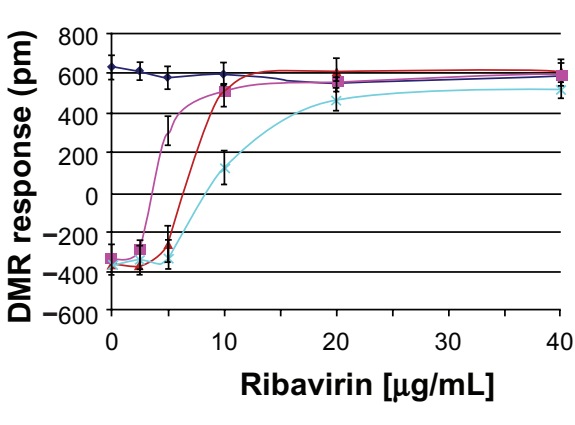

C

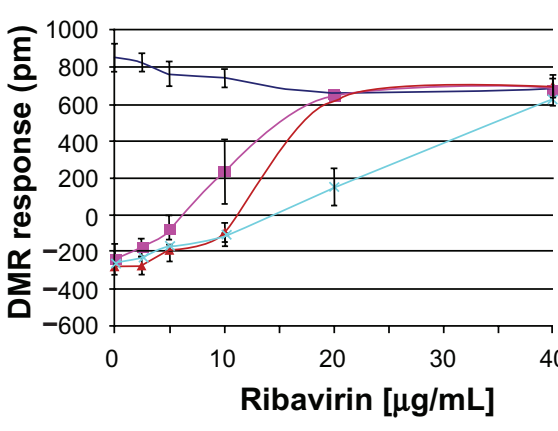

\begin{tabular}{|l|c|}
\hline & $18 \mathrm{~h}$ \\
\hline & $\mathrm{EC}_{50}(\mu \mathrm{g} / \mathrm{mL})$ \\
\hline $\mathrm{MOI}=1$ & $3.8(15 \mu \mathrm{M})$ \\
\hline $\mathrm{MOI}=2$ & $4.5(18 \mu \mathrm{M})$ \\
\hline $\mathrm{MOI}=5$ & $7.5(31 \mu \mathrm{M})$ \\
\hline
\end{tabular}

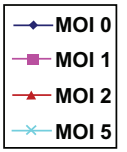

MOI 5



\begin{tabular}{|l|c|}
\hline & $24 h$ \\
\hline & $\mathrm{EC}_{50}(\mu \mathrm{g} / \mathrm{mL})$ \\
\hline $\mathrm{MOI}=1$ & $3.8(15 \mu \mathrm{M})$ \\
\hline $\mathrm{MOI}=2$ & $6.9(28 \mu \mathrm{M})$ \\
\hline $\mathrm{MOI}=5$ & $10(41 \mu \mathrm{M})$ \\
\hline
\end{tabular}

\begin{tabular}{|c|c|}
\hline & $42 h$ \\
\hline & $\mathrm{EC}_{50}(\mu \mathrm{g} / \mathrm{mL})$ \\
\hline $\mathrm{MOI}=1$ & $11.3(46 \mu \mathrm{M})$ \\
\hline $\mathrm{MOI}=2$ & $14.4(59 \mu \mathrm{M})$ \\
\hline $\mathrm{MOI}=5$ & $26.9(11 \mu \mathrm{M})$ \\
\hline
\end{tabular}

Figure 5 Dose response of ribavirin at different MOI and timepoints. MDCK cells (6000 cells/well) were seeded into FN microplate and incubated for 4 h. Ribavirin was added to MDCK cells in plate format as shown in Appendix I and incubated for I h. Cells were infected at MOI I, 2 and 5 after I h incubation and plate was read at I8 h, $24 \mathrm{~h}$ and $42 \mathrm{~h}$ virus post-infection. MDCK cells DMR response A) at $18 \mathrm{~h}$ virus post-infection, B) at $24 \mathrm{~h}$ virus post-infection and C) at $42 \mathrm{~h}$ virus post-infection with 3 different MOls.

The dose response of ribavirin was tested under these final defined assay conditions. The $\mathrm{EC}_{50}$ value is determined as the point at which the ribavirin titration curve intersects with the $50 \%$ cell viability mark. MDCK cells showed more than $90 \%$ cells viability with $40 \mu \mathrm{M}$ ribavirin addition (Figure 7). The $\mathrm{EC}_{50}$ was $18 \mu \mathrm{M}$ which is similar as the previous test as shown in Figure 5.

\section{Implementation of the DMR assay in a screen of small molecules}

We screened 1120 compounds from Prestwick Chemical Library ${ }^{\circledR}$ against influenza virus $\mathrm{A} / \mathrm{Udorn} / 72$ using the optimized DMR assay. We identified 29 compounds that showed more than $50 \%$ inhibition of the virus based on the DMR signal for a "hit" rate of $2.58 \%$. Fifteen compounds showed $>30 \%-50 \%$ inhibition and another 20 compounds showed 20\%-30\% inhibition (Figure 8).

\section{Discussion}

Application of the HTS principles and practices to antiviral drug discovery are limited by current constraints in the biology of the virus and the available detection technology. Additionally, emerging viruses present a number of unique challenges in drug discovery efforts, including limited 
A

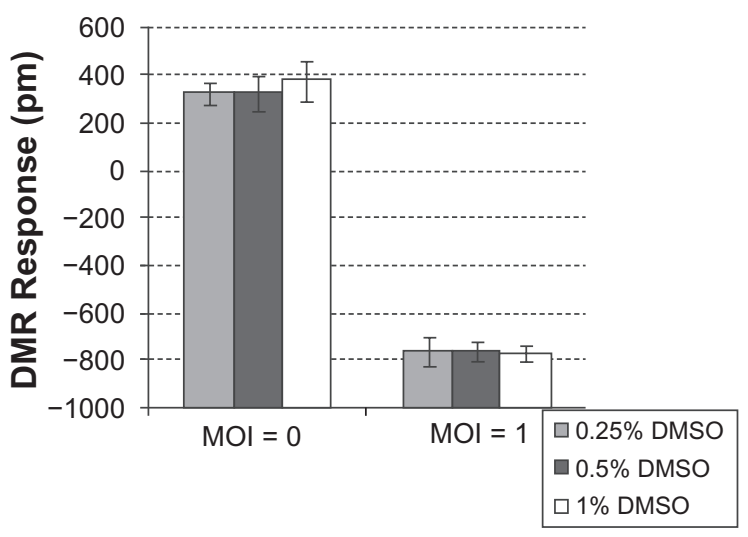

B

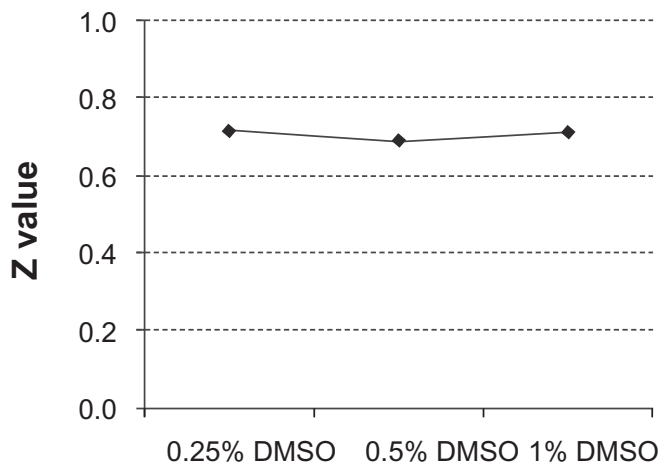

Figure $6 \mathrm{Z}$ value comparisons at different DMSO concentrations. MDCK cells ( 6000 cells/well) were seeded into FN-coated microplates and incubated for $4 \mathrm{~h}$. The assay medium was added to MDCK cells at a final concentration of DMSO at $0.25 \%, 0.5 \%$ and I\% and incubated for I h. Cells were infected with influenza virus at an MOI of I and plates were read at $18 \mathrm{~h}$ virus post-infection; A) DMR response comparison in MDCK cells at three DMSO concentrations and $\mathbf{B}) \mathrm{Z}$ value comparison in MDCK cells at three DMSO concentrations.

reagents, timely access to viral strains, biocontainment requirements, and availability of trained scientists. Generally, the majority of HT screens for antiviral drug discovery have focused on viral protein/enzyme-based targets, viral replicons with luminescent reporters or measuring the $\mathrm{CPE}$ of a virus in living cells. CPE-based screens for the identification of antivirals are well now established for arenaviruses, coronaviruses and orthomyxoviruses. For example, chemiluminescent endpoints are compatible with HTS using CPE as an endpoint for detection, and recently, have been used in antiviral drug screening for influenza virus, ${ }^{4,13}$ SARS $\mathrm{CoV}^{12}$ Tacaribe virus ${ }^{3}$ and West Nile Viruses (WNV). ${ }^{1}$ In addition,

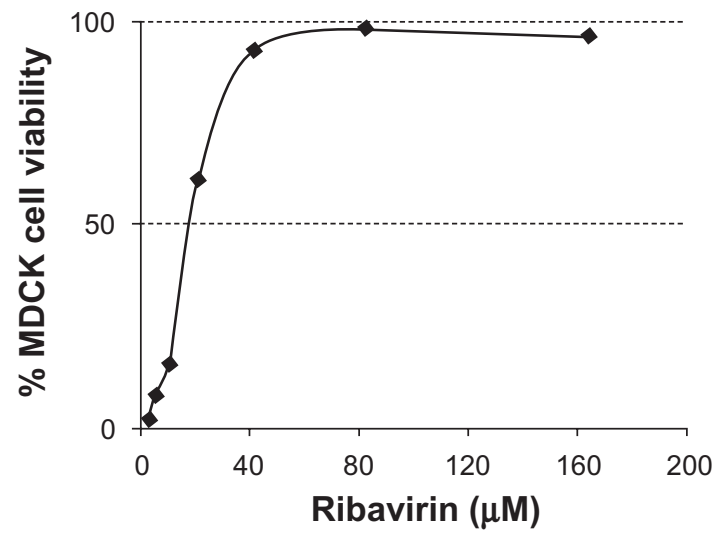

Figure 7 Dose response curve of ribavirin. Two-fold serial diluted ribavirin (from 0.625 to $40 \mu \mathrm{g} / \mathrm{ml}$ or from $2.56 \mu \mathrm{M}$ to $164 \mu \mathrm{M}$ ) were added to MDCK cells (seeded at 6000 cells per well in FN plates and incubated for $4 \mathrm{~h}$ ) and incubated for $\mathrm{I} \mathrm{h}$ followed by influenza virus infection at an $\mathrm{MOI}$ of $\mathrm{I}$. The plate was read after $18 \mathrm{~h}$ virus post-infection. The $\mathrm{EC}_{50}$ and cell viability percentage were determined as described in the Materials and Methods.
WNV replicons have been created which harbor luciferase or GFP alone ${ }^{14,15}$ or replicons with luciferase and $\mathrm{Neo}^{\mathrm{r}}$ reporters. ${ }^{16}$ The replicons have been developed in a 96-well format, and validated with known inhibitors of WNV.1, A cell-based assay using GFP-tagged human parainfluenza virus 3 (HPAIV3), a member of the Paramyxoviridae, has been successfully used to identify seven small molecules with antiviral activity from a library of compounds. ${ }^{17}$ However, a vast number of viruses do not have features (eg, reverse genetics, infectious clones), phenotypes (eg, CPE) or cell lines (eg, primary cells) that permit labeling or tracking technology for HTS measurement of endpoints. This bottle neck in HTS encouraged our group to work with the Corning ${ }^{\circledR}$ Epic $^{\circledR}$ System. In contrast to the aforementioned approaches in detection of virus, the Epic ${ }^{\circledR}$ System did not require addition of a reagent or tag for detection of the virus.

The Corning ${ }^{\circledR}$ Epic $^{\circledR}$ System enables a label-free detection HTS platform that utilizes resonant waveguide grating sensors for cell-based assays. The detection principles for performing whole cell assays are based on changes in local index of refraction that are manifested by a shift in response of the sensor. The sensors in each well detect index of refraction changes that occur within the first $200 \mathrm{~nm}$ from the sensor surface. This surface sensitivity means that only the bottom portion of whole cells cultured on the sensor are monitored during an assay. When endogenous macromolecules within the cytoplasm of mammalian cells move into or out of the sensing volume, a change in the local index of refraction is induced which leads to a shift in sensor response. Moreover, if in response to a stimulus, the cell changes 


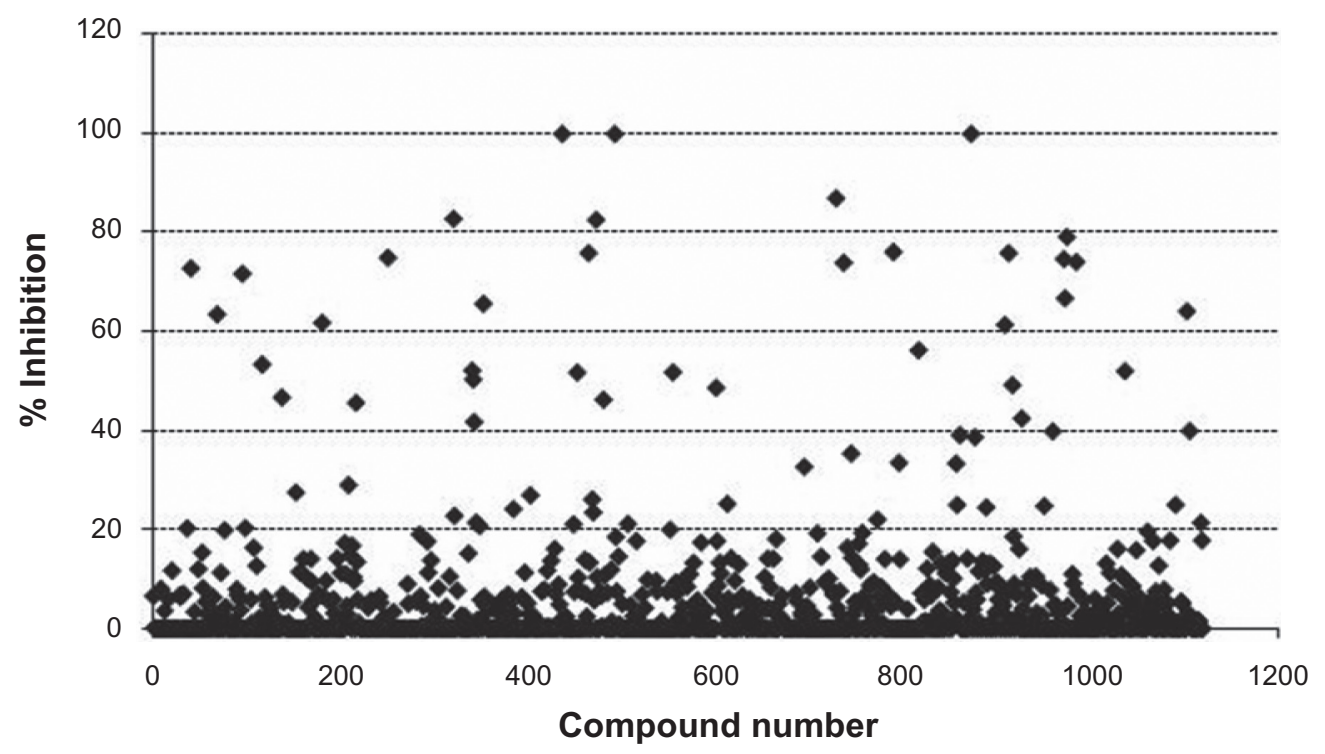

Figure 8 Screen of the Prestwick Chemical Library ${ }^{\circledR}$. MDCK cells were seeded into FN plates at 6000 cells per well and incubated at $37^{\circ} \mathrm{C}, 5 \% \mathrm{CO}_{2}$ for 4 h. Compounds were added in the plate format as shown in Appendix 2 at a final concentration of $10 \mu \mathrm{g} / \mathrm{mL}$ with $0.5 \%$ DMSO, followed by I h incubation. MDCK cells were infected with Influenza virus at an $\mathrm{MOI}$ of I and were read at $18 \mathrm{~h}$ post-infection. The inhibition effects (\% inhibition) were assessed as described in the Materials and Methods.

shape, or the endogenous material within the cell that is in close proximity to the sensor reorganizes, a shift in sensor response is induced. Thus, the Epic ${ }^{\circledR}$ System is sensitive to whole cell movement, as well as DMR within a cell due to protein trafficking. Some examples of label-free cell-based assays for the Epic ${ }^{\mathrm{TM}}$ System, include signal transduction (EGFRs, GPCRs, cytoskeleton modulators), toxicity screening, lipid signaling, and cell proliferation (for examples see $\left.^{18-20}\right)$. At present, however, this technology has only had limited applications in the study of viral infection ${ }^{21}$ and to our knowledge these are the first data in the assessment of assays that demonstrate use of the system for screening of compound libraries for antiviral drug discovery.

Armed with the basic principles of the Epic ${ }^{\circledR}$ System and our prior experience with CPE-based assays on RNA viruses, including influenza, ${ }^{4,13}$ we designed a series of experiments to adapt the instrument for screening of antivirals for influenza virus. We employed our previous parameters for HTS for influenza virus as bench marks in establishment of the assay. Since one of the disadvantages of our prior screens was the length of time (3 days) required to obtain an optimal signal window, we sought to examine the signal window at various times (eg, 4, 18, 24, 42 hours) after infection. while we titrated cell density, viral MOI and the plate surface composition. Our experiments revealed that the greatest signal could be obtained at 42 hours, but the best $\mathrm{EC}_{50}$ values were obtained at 18 hours. The lower MOI values were also better for optimal $\mathrm{EC}_{50}$. DMSO concentrations were similar to those employed in our CPE assays. In our standard CPE assays that employ chemiluminescent substrates, we do not normally employ a surface coating. However, as presented herein, these coatings will enhance performance and stability of the Epic ${ }^{\circledR}$ System assays.

In the assessment of the Epic ${ }^{\circledR}$ System by Owens et al, HeLa cells were infected with the human rhinovirus. ${ }^{21}$ As we demonstrated in our experiments, the signal varied with the amount of virus. In their studies, the greatest signal was observed with 10 plaque forming units (PFU) per cell. In our studies, we found that an MOI of 1 PFU pre cell was sufficient to obtain an optimal signal window. One of the primary differences in the life cycles of these two viruses is their mode of binding to the host cell although both viruses enter cells via receptor mediated endocyctosis. The human rhinoviruses bind Inter-Cellular Adhesion Molecule 1 (ICAM-1) receptor on endothelial cells. In contrast, influenza virus binds to sialic acid glycan residues on the cell surface. Clearly, both viruses cause internal changes with the cell as they are brought in through the endosomes, released, interact with cellular proteins and are released or lyse the cell. This is supported by the DMR signals obtained for both viruses.

\section{Conclusions}

The Corning Epic ${ }^{\circledR}$ system provides a viable alternative to the current HTS approaches in antiviral drug discovery particularly for those viruses that do not permit chemiluminescent or reporter-based methods for detection. This system could be adapted for HTS with the appropriate instrument adaptation to permit full automation, and most certainly will be valuable 
in secondary assays. Further, the RWG assay reduced the time for signal detection, reagents and number of steps and offers a similar level of sensitivity in detection of antiviral activity as compared to our current HTS for influenza. ${ }^{4}$ The Epic $^{\circledR}$ system and the assay we developed should be easily adapted for screening of small molecules for other viruses. Adaptation of the Epic ${ }^{\circledR}$ system for screening with primary cell culture systems would offer more physiologicallyrelevant systems for drug screening.

\section{Acknowledgments/disclosures}

The authors report no conflicts of interest in this work. This effort was supported by NIH Contract N01-AI-30047 at Southern Research Institute.

\section{References}

1. Puig-Basagoiti F, Deas TS, Ren P, et al. High-throughput assays using a luciferase-expressing replicon, virus-like particles, and full-length virus for West Nile virus drug discovery. Antimicrob Agents Chemother. 2005;49:4980-4988.

2. O'Boyle DR 2nd, Nower PT, Lemm JA, et al. Development of a cellbased high-throughput specificity screen using a hepatitis $\mathrm{C}$ virus-bovine viral diarrhea virus dual replicon assay. Antimicrob Agents Chemother. 2005;49:1346-1353.

3. Bolken TC, Laquerre S, Zhang Y, et al. Identification and characterization of potent small molecule inhibitor of hemorrhagic fever New World arenaviruses. Antiviral Res. 2006;69:86-97.

4. Severson WE, McDowell M, Ananthan S, et al. High-throughput screening of a 100,000-compound library for inhibitors of influenza A virus (H3N2). J Biomol Screen. 2008;13:879-887.

5. Szabo A, Stolz L, Granzow R. Surface plasmon resonance and its use in biomolecular interaction analysis (BIA). Curr Opin Struct Biol. 1995;5: 699-705.

6. Cooper MA. Label-free screening of bio-molecular interactions. Anal Bioanal Chem. 2003;377:834-842.

7. Maynard JA, Lindquist NC, Sutherland JN, et al. Surface plasmon resonance for high-throughput ligand screening of membrane-bound proteins. Biotechnol J. 2009;4:1542-1558.
8. Peters MF, Vaillancourt F, Heroux M, et al. Comparing label-free biosensors for pharmacological screening with cell-based functional assays. Assay Drug Dev Technol. 2010; Jan 19 [Epub ahead of print].

9. Cox NJ, Fukuda K. Influenza. Infect Dis Clin North Am. 1998; $12: 27-38$

10. Thompson WW, Shay DK, Weintraub E, et al. Influenza-associated hospitalizations in the United States. JAMA. 2004;292:1333-1340.

11. Khazeni N, Hutton DW, Garber AM, et al. Effectiveness and costeffectiveness of expanded antiviral prophylaxis and adjuvanted vaccination strategies for an influenza A (H5N1) pandemic. Ann Intern Med. 2009;151:840-853.

12. Severson WE, Shindo N, Sosa M, et al. Development and validation of a high-throughput screen for inhibitors of SARS CoV and its application in screening of a 100,000-compound library. J Biomol Screen. 2007; $12: 33-40$.

13. Noah JW, Severson W, Noah DL, et al. A cell-based luminescence assay is effective for high-throughput screening of potential influenza antivirals. Antiviral Res. 2007;73:50-59.

14. Rossi SL, Zhao Q, O'Donnell VK, et al. Adaptation of West Nile virus replicons to cells in culture and use of replicon-bearing cells to probe antiviral action. Virology. 2005;331:457-470.

15. Noueiry AO, Olivo PD, Slomczynska U, et al. Identification of novel small-molecule inhibitors of West Nile virus infection. $J$ Virol. 2007;81:11992-12004.

16. Ng CY, Gu F, Phong WY, et al. Construction and characterization of a stable subgenomic dengue virus type 2 replicon system for antiviral compound and siRNA testing. Antiviral Res. 2007;76:222-231.

17. Mao H, Thakur CS, Chattopadhyay S, et al. Inhibition of human parainfluenza virus type 3 infection by novel small molecules. Antiviral Res. 2008;77:83-94.

18. O'Malley SM, Xie X, Frutos AG. Label-free high-throughput functional lytic assays. J Biomol Screen. 2007;12:117-125.

19. Fang Y, Ferrie AM. Label-free optical biosensor for ligand-directed functional selectivity acting on beta(2) adrenoceptor in living cells. FEBS Lett. 2008;582:558-564.

20. Tran E,Ye F. Duplexed label-free G protein - coupled receptor assays for high-throughput screening. J Biomol Screen. 2008;13:975-985.

21. Owens RM, Wang C, You JA, et al. Real-time quantitation of viral replication and inhibitor potency using a label-free optical biosensor. J Recept Signal Transduct Res. 2009;29:195-201. 


\section{Appendices}

Total volume $(45 \mu \mathrm{L}): 20 \mu \mathrm{L}$ cell $+5 \mu \mathrm{L}(9 \mathrm{X})$ drug in $2.5 \% \%$ DMSO $+20 \mu \mathrm{L}$ virus

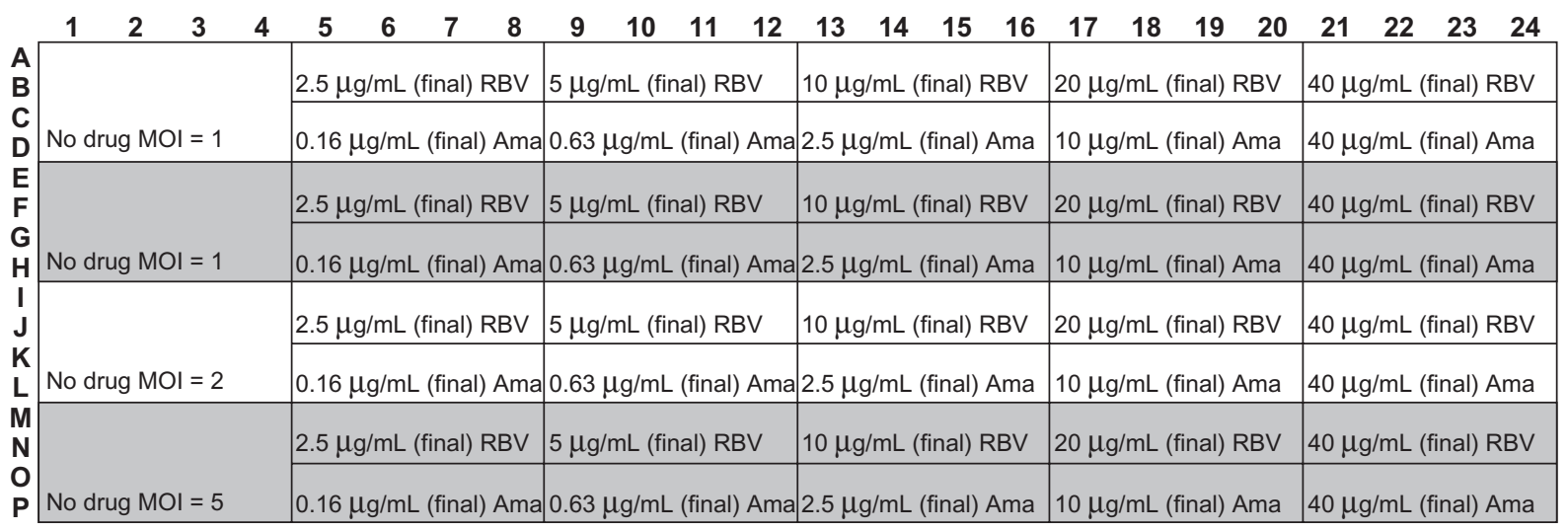

Appendix I Ribavirin dose response plate format.

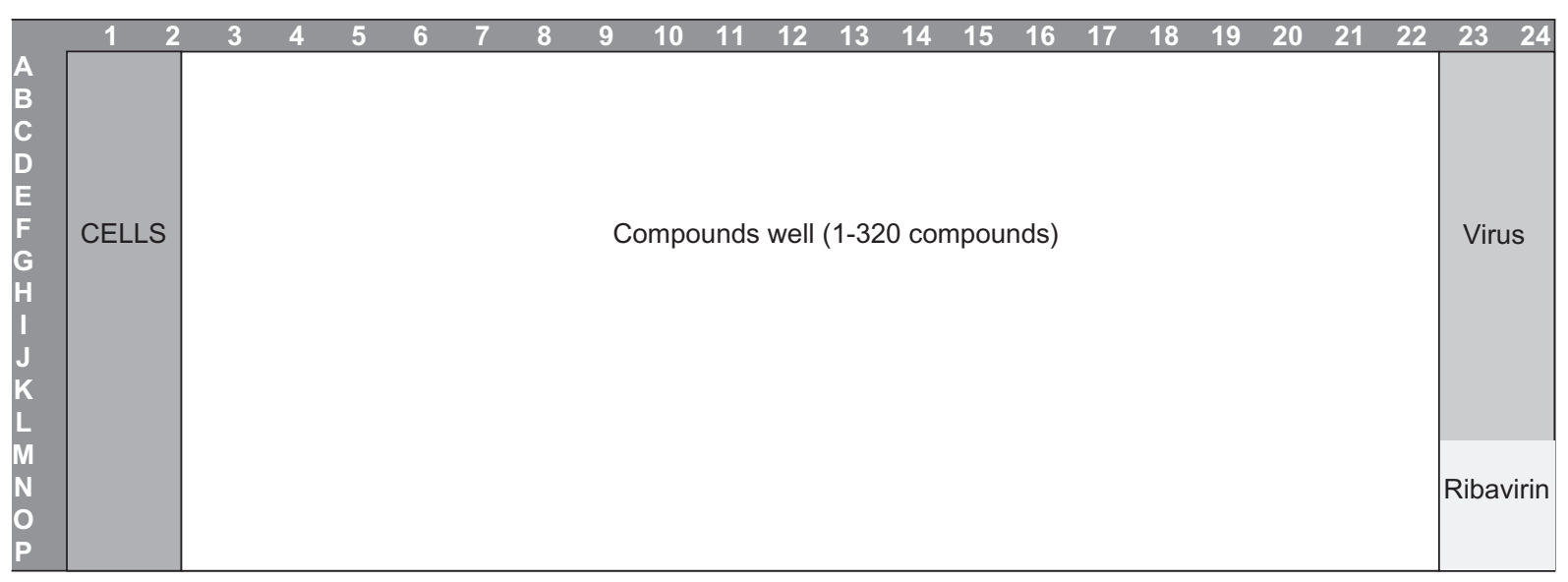

Appendix 2 Preswick library screening plate format.

International Journal of High Throughput Screening

\section{Publish your work in this journal}

International Journal of High Throughput Screening is an international, peer-reviewed, open access journal publishing original research, reports, editorials, reviews and commentaries dedicated to all aspects of high throughput screening, especially related to drug discovery and associated areas of biology and chemistry. The manuscript management sys-
Dovepress

tem is completely online and includes a very quick and fair peer-review system. Visit http://www.dovepress.com/testimonials.php to read real quotes from published authors.

Submit your manuscript here: http://www.dovepress.com/international-journal-of-high-throughput-screening-journal 